\title{
How Blood Vessel Networks Are Made and Measured
}

\author{
John C. Chappell ${ }^{a, b}$ David M. Wiley ${ }^{a, b}$ Victoria L. Bautch ${ }^{a-c}$ \\ ${ }^{\mathrm{a}}$ Department of Biology, ${ }^{\mathrm{b}}$ McAllister Heart Institute, and ${ }^{\mathrm{C}}$ Lineberger Comprehensive Cancer Center, \\ The University of North Carolina at Chapel Hill, Chapel Hill, N.C., USA
}

\section{Key Words}

Blood vessel formation · Angiogenesis • Vessel sprouting models, measurements

\begin{abstract}
Tissue and organ viability depends on the proper systemic distribution of cells, nutrients, and oxygen through blood vessel networks. These networks arise in part via angiogenic sprouting. Vessel sprouting involves the precise coordination of several endothelial cell processes including cell-cell communication, cell migration, and proliferation. In this review, we discuss zebrafish and mammalian models of blood vessel sprouting and the quantification methods used to assess vessel sprouting and network formation in these models. We also review the mechanisms involved in angiogenic sprouting, and we propose that the process consists of distinct stages. Sprout initiation involves endothelial cell interactions with neighboring cells and the environment to establish a specialized tip cell responsible for leading the emerging sprout. Furthermore, local sprout guidance cues that spatially regulate this outward migration are discussed. We also examine subsequent events, such as sprout fusion and lumenization, that lead to maturation of a nascent sprout into a patent blood vessel.
\end{abstract}

Copyright ๑ 2011 S. Karger AG, Basel

\section{Introduction}

The formation of blood vessel networks is essential to providing oxygen and nutrients to virtually all organs and tissues in the organism. Once a few nascent vessels are formed via a process called vasculogenesis, the further expansion of vessel networks in development proceeds via a combination of proliferation and migration called sprouting angiogenesis [Risau, 1997]. Angiogenesis is also essential to pathological blood vessel formation that is associated with diseases as diverse as cancer and diabetes [Aiello, 2008; Heath and Bicknell, 2009; Fioretto

\begin{tabular}{ll}
\hline Abbreviations used in this paper \\
\hline BMP & $\begin{array}{l}\text { bone morphogenic protein } \\
\text { days postfertilization } \\
\text { dpf }\end{array}$ \\
ECM & $\begin{array}{l}\text { extracellular matrix } \\
\text { enhanced green fluorescent protein }\end{array}$ \\
eGFP & embryonic stem \\
ES & fibroblast growth factor \\
FGF & human umbilical vein endothelial cells \\
HUVEC & intersegmental arteries \\
ISAs & leukemia inhibitory factor \\
LIF & Notch intracellular domain \\
NICD & platelet-derived growth factor \\
PDGF &
\end{tabular}

Accessible online at:
www.karger.com/cto 


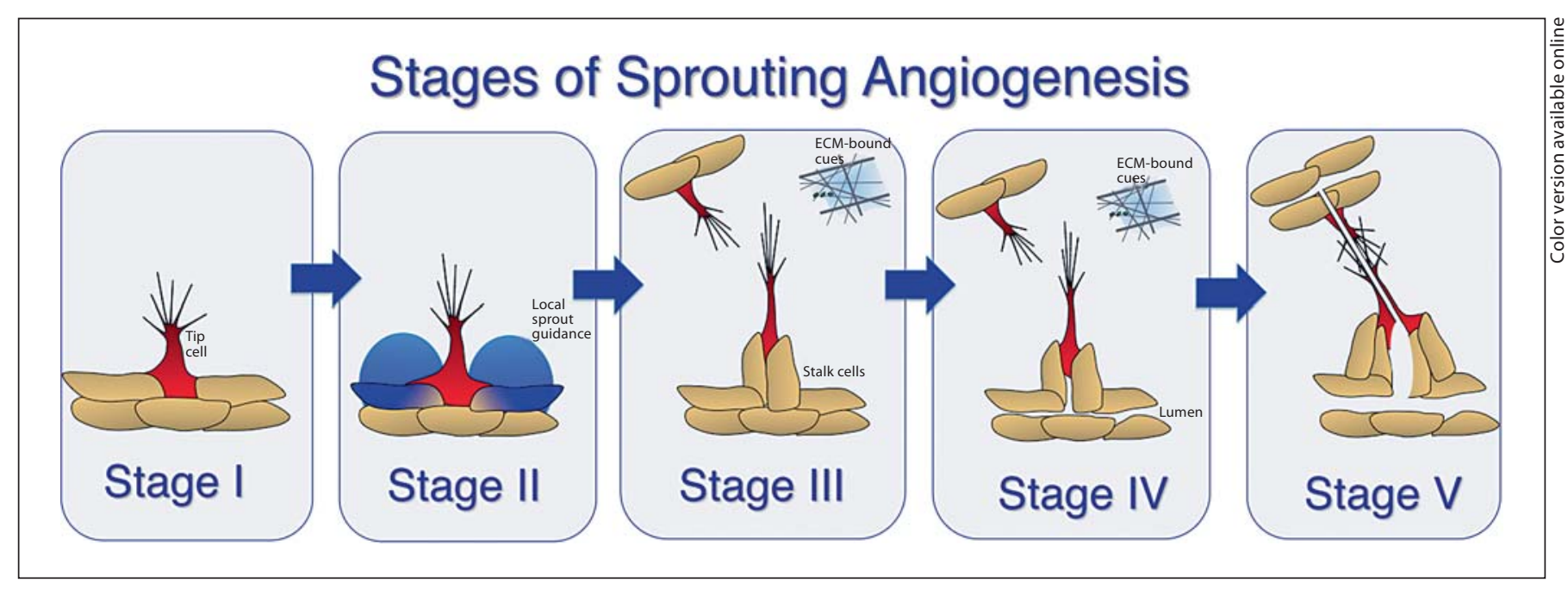

Fig. 1. Stages of blood vessel sprouting. We propose that blood vessel sprouting occurs in distinct stages characterized by specific cellular processes and specific (although partially overlapping) molecular requirements. Stage I is tip cell specification and sprout initiation that occurs by poorly understood processes; stage II is sprout elongation and local guidance that features VEGF/Flt-1 near-field interactions; stage III is sprout elongation in response to extrinsic cues; stage IV is lumen formation, and stage $\mathrm{V}$ is sprout fusion and completion of lumenization to produce a new vessel connection capable of blood flow. et al., 2010]. The last 10 years of research have produced elegant models of sprouting angiogenesis as better experimental tools and model systems have become available. Specifically, the ability to selectively delete genes in developing mouse vessels using vascular-specific Cre driver mouse lines and mice with loxP recombination sites in genes has allowed us to assess the specific function of genes in mammalian vascular development. The ability to regulate excision temporally via inducible Cre driver lines has also allowed researchers to focus on genetic requirements at the developmental time that requires sprouting angiogenesis. These advances have been complimented by extensive improvements in our ability to assess vessel sprouting - from confocal microscopy with numerous vessel markers to the development of live imaging techniques in several models, including the genetically tractable zebrafish. This combination of precise genetic tools with novel technology to query cell-based behaviors has proven powerful in advancing our understanding of how blood vessel sprouting is regulated.

Briefly, sprouting angiogenesis is comprised of several distinct steps, and we believe that the following classification reflects different temporal and/or regulatory nodes (fig. 1). First, an endothelial cell within a nascent vessel initiates sprouting by responding to chemotactic cues and extending filopodia (fig. 1, stage I). It is not clear how the 'tip' cell is initially specified, although subsequently there is a competition for the tip cell position, with cells experiencing elevated VEGF signaling at an advantage for tip cell position over neighbors with less VEGF signaling [Jakobsson et al., 2010]. Once the tip cell begins to move out, local guidance cues help ensure that the newly emerging sprout moves away from the parent vessel instead of rejoining it, and the soluble form of the VEGF receptor VEGFR-1 (Flt-1) is implicated in this guidance [Chappell et al., 2009] (fig. 1, stage II). As the sprout continues to extend, several changes occur (fig. 1, stage III). First, the sprout leaves the environment of local guidance cues and becomes capable of responding to cues from the microenvironment and/or other vessels or sprouts. It also now has cells behind the leading tip cell, called 'stalk cells', that are more likely to undergo cell division than the tip cell. Finally, as the sprout extends, lumens begin to form by poorly understood processes (fig. 1, stage IV). The final stages of sprouting angiogenesis involve cellcell interactions that lead to fusion of the tip cell with another sprout tip cell or a vessel and the formation of a patent lumen that provides a new conduit (fig. 1, stage V). The outcomes of sprouting angiogenesis are an expanded vessel network that delivers oxygen and nutrients to tissues, and a plexus that can be subsequently remodeled by physiological cues such as blood flow.

In this brief review we focus on recent advances in our understanding of sprouting angiogenesis, and we 
discuss methods for quantification of vessel sprouting that have been developed by our group and others. The ability to measure precise quantitative parameters has allowed researchers to provide statistical significance to abnormalities as well as reveal more subtle perturbations of sprouting angiogenesis. We refer the reader to numerous recent reviews that cover aspects of angiogenesis in more detail [Roca and Adams, 2007; Iruela-Arispe and Davis, 2009; Phng and Gerhardt, 2009; Chappell et al., 2011].

\section{Blood Vessel Sprouting in Zebrafish}

Zebrafish are transparent as embryos and undergo rapid development, which provides a unique system for imaging angiogenesis in vivo [Lawson and Weinstein, 2002]. Zebrafish are highly conducive to the use of antisense oligomers known as morpholinos that can block gene expression and create gene 'knockout' scenarios [Eisen and Smith, 2008]. In addition, genetic and molecular tools available in zebrafish are continuing to expand.

\section{Regions of Vessel Sprouting}

Blood begins to circulate at $24 \mathrm{~h}$ postfertilization in zebrafish. The primitive circulatory loop in zebrafish is composed of the dorsal aorta and cardinal vein. The intersegmental arteries (ISAs) initially sprout from the dorsal aorta between 1 day postfertilization (dpf) and 2 dpf and form chevron-shaped vessels [Isogai et al., 2003]. The quick development and stereotypical morphology of the ISAs makes them useful for studying angiogenesis. While the ISAs have received the most attention for studying zebrafish angiogenesis, other sites are the focus of recent studies, including vascularization of the gut and fins [Hu et al., 2006; Ma et al., 2007], formation of the aortic arches [Nicoli et al., 2010], and sprouting from the posterior caudal vein [Hermans et al., 2010; Wiley et al., 2011].

The ISAs form between somites via migratory movements restricted by the somites [Childs et al., 2002]. The somites provide important chemotactic cues such as VEGF [Lawson et al., 2002], and they also act as a physical barrier by which these stereotypical blood vessels are guided. However, many vascular beds form without physical barriers, and consequently they rely more heavily on the free movements of endothelial sprouts to form proper connections and expand. An example of 'free forming' angiogenesis in the zebrafish is the development of the caudal vein plexus in the sparsely populated regions near the tail. The formation of this plexus involves dynamic endothelial cell movements and intercellular communication. Interestingly, the stereotypical ISAs sprout in response to VEGF signaling, whereas the 'free forming' caudal vein plexus is uniquely dependent on bone morphogenetic protein (BMP) signaling for sprouting angiogenesis [Wiley et al., 2011]. Thus, BMP stimulates venous sprouting even with disruption of VEGF signaling, suggesting that the two pathways regulate arterial and venous angiogenic sprouting independently.

\section{Quantification Methods in Zebrafish}

The expanded use of the zebrafish to study sprouting angiogenesis has occurred largely through the development of vascular-specific reporters and advances in imaging techniques. The $f l i 1$ and $f l k l$ genes are used to drive expression of enhanced green fluorescent protein (eGFP) in the developing zebrafish vasculature [Cha and Weinstein, 2007]. Multiphoton imaging of these reporter fish facilitates long-term, dynamic imaging of blood vessels during their formation [Kamei et al., 2010], which has led to many important insights into vessel sprouting. In addition, systems for screening pro- and antiangiogenic agents have been developed using these reporter lines [Tran et al., 2007].

There are numerous ways to quantify angiogenic events and to score defects in zebrafish blood vessel formation. The penetrance of an angiogenic defect can be represented by simply determining the percentage of embryos that contain the defect. However, angiogenic perturbations are often complex and diverse. Therefore, it is often more informative to sort zebrafish into different classes that reflect the severity of the angiogenic disruption. The percentage of embryos in each class is then used to represent the diversity of angiogenic defects. An alternative way to represent the severity of a phenotype is to determine the percentage of segments per embryo that contain a specified disturbance, where each segment is defined as the area on the anterior-posterior axis between two adjacent somite boundaries. For example, normal ISA development would result in 1 sprout/segment, while excess sprouting from the dorsal aorta or ISAs would result in $>1$ sprout/segment. One can also use the segment boundaries to quantify ectopic vessels, an example being quantification of the ectopic sprouting from the caudal vein in embryos overexpressing Bmp2 [Wiley et al., 2011]. It is predicted that other quantification protocols will be developed as distinct vascular beds within the developing zebrafish are studied in the future. 


\begin{tabular}{|c|c|c|c|c|c|}
\hline Model & Description & Strengths & Limitations & Sketch & References \\
\hline $\begin{array}{c}\text { Fibrin or } \\
\text { Collagen Bead } \\
\text { Assay }\end{array}$ & $\begin{array}{l}\text { Microcarrier beads coated with } \\
\text { primary endothelial cells } \\
\text { (e.g. HUVEC), embedded in fibrin } \\
\text { and supplied with exogenous } \\
\text { growth factors (e.g. VEGF) }\end{array}$ & $\begin{array}{l}\text { - Ease of experimental } \\
\text { manipulation } \\
\text { - Dynamic and fixed } \\
\text { imaging possible }\end{array}$ & $\begin{array}{l}\text { - Limited incorporation } \\
\text { of mechanical inputs } \\
\text { - Endothelial cells from } \\
\text { generic source }\end{array}$ & & $\begin{array}{l}\text { [Nakatsu and } \\
\text { Hughes, 2008] }\end{array}$ \\
\hline $\begin{array}{l}\text { Attached } \\
\text { Embryoid Body } \\
\text { Model }\end{array}$ & $\begin{array}{l}\text { Embryoid bodies attached to tissue } \\
\text { culture plastic and cultured for } 8 \\
\text { days }\end{array}$ & $\begin{array}{l}\text { - Live and fixed imaging } \\
\text { possible } \\
\text { - Intact genetic programs } \\
\text { - Other cell types included }\end{array}$ & $\begin{array}{l}\text { - Lacks mechanical and } \\
\text { systemic inputs } \\
\text { associated with blood } \\
\text { flow }\end{array}$ & & $\begin{array}{c}\text { [Zeng and } \\
\text { Bautch, 2009] }\end{array}$ \\
\hline $\begin{array}{l}\text { Collagen- } \\
\text { embedded } \\
\text { Embryoid Body } \\
\text { Model }\end{array}$ & $\begin{array}{l}\text { Embryoid bodies embedded in } \\
\text { collagen and exposed to } \\
\text { exogenous growth factors (e.g. } \\
\text { VEGF) over } 8 \text { days }\end{array}$ & $\begin{array}{l}\text { - In the context of other cell } \\
\text { types (e.g. pericytes) } \\
\text { - Distinct sprouting allows } \\
\text { easy visualization }\end{array}$ & $\begin{array}{l}\text { - Lacks mechanical and } \\
\text { systemic inputs } \\
\text { associated with blood } \\
\text { flow }\end{array}$ & & [Li et al., 2008] \\
\hline $\begin{array}{c}\text { Allantois } \\
\text { Culture Model }\end{array}$ & $\begin{array}{l}\text { Embryonic (E7.5-8) allantois } \\
\text { explanted and cultured } \\
\text { for } 1 \text { to } 2 \text { days }\end{array}$ & $\begin{array}{l}\text { - In vivo genetic programs } \\
\text { intact }\end{array}$ & $\begin{array}{l}\text { - Frequency of sprouting } \\
\text { events may be limited }\end{array}$ & & $\begin{array}{l}\text { [Downs et al., } \\
\text { 2001] }\end{array}$ \\
\hline $\begin{array}{l}\text { Postnatal Mouse } \\
\text { Retina }\end{array}$ & $\begin{array}{l}\text { From postnatal day } 0 \text { to } 8 \text {, } \\
\text { vasculature expands out radially } \\
\text { from optic nerve primarily through } \\
\text { sprouting angiogenesis }\end{array}$ & $\begin{array}{l}\text { - Robust sprouting occurs } \\
\text { - Thin tissue for easy } \\
\text { observation }\end{array}$ & $\begin{array}{l}\text { - Substantial } \\
\text { heterogeneity in } \\
\text { vessel morphology } \\
\text { within a single retina }\end{array}$ & & $\begin{array}{l}\text { [Pitulescu et al., } \\
\text { 2010] }\end{array}$ \\
\hline $\begin{array}{l}\text { Rat Mesentery } \\
\text { Model }\end{array}$ & $\begin{array}{l}\text { Adult rat mesentery exposed to } \\
\text { inflammatory stimulus and vessels } \\
\text { invade avascular mesenteric } \\
\text { windows }\end{array}$ & $\begin{array}{l}\text { - Thin tissue facilitates } \\
\text { clear imaging of sprouting } \\
\text { tip cells }\end{array}$ & $\begin{array}{l}\text { - Tools available for } \\
\text { genetic manipulation } \\
\text { limited }\end{array}$ & & $\begin{array}{c}\text { [Anderson et al., } \\
\text { 2004] }\end{array}$ \\
\hline $\begin{array}{l}\text { Tumor } \\
\text { Angiogenesis } \\
\text { Model }\end{array}$ & $\begin{array}{l}\text { Isolation of angiogenic vessels } \\
\text { within tumors }\end{array}$ & $\begin{array}{l}\text { - Highly relevant disease } \\
\text { model }\end{array}$ & $\begin{array}{l}\text { - Tumor heterogeneity } \\
\text { hinders interpretation } \\
\text { - Live imaging difficult }\end{array}$ & & $\begin{array}{l}\text { [Ocak et al., } \\
\text { 2007] }\end{array}$ \\
\hline
\end{tabular}

Fig. 2. Mammalian models of blood vessel sprouting. Summary of strengths and limitations for each model discussed, as well as a general schematic of each model and reference to a publication with detailed methods for utilizing the model, although multiple publications describe and use most models. Green cells represent endothelial cells, and tan cells represent other cell types present in each model. The gray sphere in the fibrin bead assay category represents the microcarrier bead to which the endothelial cells attach, and the gray area in the rat mesentery assay represents the connective tissue within a mesenteric loop.

\section{Blood Vessel Sprouting in Mammalian Systems}

A range of mammalian-based experimental models have been developed to observe blood vessel sprouting (fig. 2). An ideal model would facilitate observation of individual endothelial cells during the sprouting process, and each cell would exhibit their behaviors in the appropriate physiological or pathological context. Here we describe several in vitro, in situ, and in vivo models commonly used to investigate angiogenic sprouting in mammalian-based systems. These three groups represent a continuum of both biological complexity and ease of manipulation. In vitro platforms are the least complex in terms of cellular inputs and environmental factors and are therefore most amenable to experimental intervention. Although slightly more difficult to manipulate, in situ models offer an increase in complexity as the cellular and environmental components of the sprouting environment more closely resemble that of vessels sprouting within an animal. In vivo approaches capture blood vessels sprouting in their most physiologically relevant context, but these models are also the most challenging to manipulate and require innovative experimental techniques. We describe the strengths and limitations of each model in providing insight into sprouting and vessel branching. Important caveats of each model system to be considered when interpreting observations are highlighted as results from a particular model or tissue site are often context dependent and not necessarily applicable to all situations.

\section{Mammalian Models of Vessel Sprouting}

This compilation of models is by no means comprehensive, but it provides examples of different categories of models and how they are used. 
In vitro Models of Vessel Sprouting

In vitro blood vessel sprouting assays recapitulate many important aspects of sprout formation. These systems are limited in modeling the full range of in vivo influences on endothelial cell sprouting, including blood flow and circulating factors. Nevertheless, this reduced complexity can be beneficial for understanding this highly dynamic process as sprouting cells and their neighbors can be readily visualized and easily manipulated. The fibrin bead assay is an in vitro model in which microcarrier beads are coated with endothelial cells such as human umbilical vein endothelial cells (HUVEC) and embedded in a fibrin matrix topped by fibroblasts that provide proangiogenic cues [Nehls and Drenckhahn, 1995; Sainson et al., 2005; Nakatsu and Hughes, 2008]. Approximately 2-4 days after embedding, endothelial cells sprout into the fibrin matrix, and new branches extend from these initial vessel-like structures at 3-5 days. A similar approach has been developed using 3-dimensional collagen matrix and endothelial cells from a variety of sources [Goto et al., 1993; Kamei et al., 2006; Koh et al., 2008; Bayless et al., 2009]. In this assay, endothelial cells are initially configured as a monolayer on top of the collagen, and within a day sprouts extend and branch down into the matrix in response to proangiogenic factors.

In these models, cells can be manipulated genetically and pharmacologically with relative ease, and live imaging by video microscopy can be complemented with fixed-image analysis to resolve individual cells and their behaviors [Nakatsu and Hughes, 2008; Bayless et al., 2009]. Furthermore, the sprouting environment can be altered by manipulating extracellular matrix (ECM) components [Bayless and Davis, 2003] or by selectively adding other cell types or molecules and determining their effects on vessel formation [Nehls et al., 1994; Dietrich and Lelkes, 2006; Liu et al., 2008; Stratman et al., 2009]. Recent studies have extended these assays further by including fluid movement to model effects of blood flow [Kang et al., 2008] and interstitial fluid flow on endothelial sprouting [Vickerman et al., 2008; Hernandez Vera et al., 2009].

In addition to the strengths discussed above, these in vitro systems also have certain limitations to be considered when interpreting observations. Important physiological features, such as mechanical inputs from tissue deformation/expansion and blood flow, are lacking in these models. Furthermore, given that the endothelial cells used often come from a generic source and not necessarily from a tissue undergoing angiogenesis, essential context-dependent cues that set up and maintain endo- thelial heterogeneity may be altered in, or even absent from, these assays. Finally, the geometry of the collagen sprouting model (i.e. the downward extension of sprouts) presents an additional limitation because it is not conducive to image analysis. Overall, in vitro models of endothelial sprouting have provided, and will continue to yield, many important insights into angiogenic sprouting and vessel branch formation, and coupling these observations with other experimental approaches will certainly elucidate essential mechanisms involved in this complex process.

\section{In situ Models of Vessel Sprouting}

Several in situ models have been developed that retain key features of in vivo vascular sprouting while offering relative ease of experimental manipulation and accessibility for live imaging. The endogenous genetic programs underlying vessel formation and morphogenesis are still present, in addition to the complex interactions between various cell types, but the macroenvironment can still be tightly controlled and manipulated for experimental purposes.

After removal of leukemia inhibitory factor (LIF) from the media, mouse embryonic stem (ES) cells undergo a programmed differentiation in standard culture conditions and form multiple cell types, including vascular endothelial cells that form primitive lumenized vessels [Doetschman et al., 1985; Risau et al., 1988; Wang et al., 1992; Jakobsson et al., 2007b; Zeng and Bautch, 2009]. Primitive vessels form via vasculogenesis and subsequent sprouting angiogenesis in a context similar to that of the developing embryo and yolk sac, particularly in terms of other cell types that provide important inductive and developmental cues, such as the underlying endoderm. This model is especially amenable to high-resolution live imaging [Kearney et al., 2004; Chappell et al., 2009] since the 3-dimensional vessels form in a relatively limited portion of the z-axis, somewhat like a pancake.

Alternatively, partially differentiated ES cells are cultured in a 3 -dimensional collagen matrix, and developing vessels are induced to sprout into the surrounding collagen through the addition of exogenous growth factors [Jakobsson et al., 2006; Li et al., 2008; Chappell et al., 2009; Jakobsson et al., 2010]. In this collagen-embedded ES cell differentiation model, different aspects of angiogenic sprouting can be investigated by analysis of both primary sprouts and the secondary branches that emerge from these initial vessels. These vessels also become lumenized [Jakobsson et al., 2007a, b]. Since the vessels sprout away from the other cell types, there is a distinct 
sprouting direction in this model. This model is also amenable to live imaging although currently at a lower resolution than is possible with vessels that form over an endoderm layer (see above).

The mouse allantois is an embryonic tissue that can be excised and cultured under conditions in which angiogenic expansion occurs [Drake and Fleming, 2000; Downs et al., 2001; Crosby et al., 2005]. This extraembryonic tissue is composed largely of mesoderm and gives rise to the chorioallantoic placenta. Primitive vessels form in the allantois between embryonic days E6.5 and E7.5 through vasculogenesis. Extraction is usually at E7.5, and subsequent culture for $24-48 \mathrm{~h}$ supports angiogenic expansion [Argraves et al., 2002; Perryn et al., 2008]. Since the initial stages of blood vessel formation occur in vivo in the context of blood flow, the plexus has normal mechanical cues prior to culture. The allantois model is also useful for analysis of mutations that are embryonic lethal post-E7.5, for analysis of complex genetic crosses, or for experimental conditions that prohibit in vivo analysis (i.e. reporter loci in a mutant background or during severely disrupted conditions). For example, Winderlich et al. [2009] utilized the GFP reporter driven by the VE-cadherin promoter to dynamically visualize allantois vessel formation during pharmacological intervention.

An approach similar to the allantois culture model is the mouse embryo culture system, in which the whole embryo including the yolk sac is isolated between 7.5 and $12.5 \mathrm{dpc}$ and cultured for $24 \mathrm{~h}$ or more [Megason and Fraser, 2003; Garcia et al., 2011]. Using this platform, sprouting events within the developing yolk sac plexus can be observed, and the tools for observing these blood vessels are expanding [Larina et al., 2009]. This approach may also serve as a means to assess embryonic lethal mutations.

One feature of these models is that blood vessel sprouting can be observed with real-time and fixed imaging, as done with in vitro models, but in the context of other physiologically relevant cell types and genetic programs [Kearney et al., 2004; Jakobsson et al., 2006; Chappell et al., 2009]. For example, the current paradigm for endothelial proliferation in sprouting angiogenesis is that the tip cell rarely divides, whereas stalk cells undergo divisions to lengthen a vessel [Gerhardt et al., 2003]. Dynamic imaging of ES cell-derived vessel sprouts, however, has revealed that tip cells sometimes retract and subsequently divide, highlighting the importance of coupling fixedimage analysis with time-lapse observations [Chappell and Bautch, unpubl. res.]. Furthermore, the additional cell populations present in these models provide important molecular cues [Ng et al., 2004], as well as essential mechanical cues [Perryn et al., 2008], that contribute to a more faithful reconstruction of the in vivo environment.

The limitations of these models of vessel sprouting should also be considered. A particular model may not include all relevant cell types in a given sprouting context, which may limit broader interpretation of the results. For example, macrophages may contribute to guiding the fusion between two sprouting endothelial cells [Fantin et al., 2010], and these macrophages may not be as abundant in the in situ models as they are in vivo. These models also lack mechanical inputs associated with blood flow. As with in vitro models, the limitations of fully recapitulating a physiological sprouting environment necessitate corroborating in situ observations with in vivo approaches.

\section{In vivo Models of Vessel Sprouting}

In vivo models of endothelial sprouting offer insight into underlying mechanisms that occur in a physiological context. These systems include the mechanical inputs from blood flow, interstitial fluid movement, and tissue deformation in addition to the effects from a wider range of cell types. Moreover, the ECM composition and physical constraints imposed by the surrounding tissue may further distinguish different in vivo sprouting environments.

Blood vessel sprouting in vivo has been investigated using several mouse models. The developing mouse retinal vasculature has recently gained significant attention. At birth, blood vessels emerge through the optic disc at the base of the retina. Over 8 days (P0 to P8), these vessels expand radially toward the outer edge of the retina, predominantly through angiogenic sprouting [Stalmans et al., 2002; Fruttiger, 2007; Pitulescu et al., 2010]. Numerous endothelial tip cells emerge from the front of this expanding vascular network, and the filopodia from these sprouting cells are prominent and useful indicators of endothelial cell behavior [Gerhardt et al., 2003; Suchting et al., 2007; Chappell et al., 2009]. Strengths of the retinal vessel model are: (1) the network does not expand extensively in the z-axis so it is ideal for confocal image analysis; (2) the vessels mature and remodel from the optic disc outward, allowing for simultaneous analysis of different stages of remodeling and clear demarcation of arterial vs. venous beds; (3) the eye is accessible for intraocular injection of drugs, antibodies, and viruses, and (4) the eye is dispensable for life so it can be dramatically locally per- 
turbed without lethality. Limitations are: (1) the vessels migrate outward over a network of astrocytes, so perturbations to this underlying astrocy te network can perturb vessel patterning, and (2) retinal vessels do not survive for significant periods of time ex vivo [Sawamiphak et al., 2010a, b], making live imaging difficult [C. Lee and VL Bautch, unpubl. res.]. Vessel sprouting and filopodial extensions from tip cells have been observed in mouse embryonic tissues as well, including the hindbrain [Ruhrberg et al., 2002; Gerhardt et al., 2004; Suchting et al., 2007; Fantin et al., 2010] and skin [Benedito et al., 2009] [Heinz and Bautch, unpubl. res.]. These sites are useful if embryonic lethality is an issue, and they provide an alternative to the retina; however, they are more difficult to access and image than the retina.

Rat models, e.g. the rat mesentery model, have also been developed for observing in vivo vascular sprouting. Following an inflammatory insult or exposure to proangiogenic factors, extensive angiogenic sprouting occurs across the mesenteric connective tissue [Anderson et al., 2004; Benest et al., 2008]. This thin tissue is amenable to confocal microscopy, comparable to the retina tissue, but the limited genetic tools available in the rat have prevented wider usage.

Angiogenic sprouting is an important aspect in a number of pathological conditions. Tumors secrete large amounts of angiogenic factors, including VEGF-A, to stimulate the in-growth and expansion of blood vessels, and thus many solid tumor models contain observable sprouting events. These sprouts experience aberrant VEGF and Notch-Delta signaling [Patel et al., 2005; Ridgway et al., 2006], which results in morphological defects such as perturbed deposition of basement membrane around vessel sprouts [Baluk et al., 2003]. Vessel sprout density and morphology observations complement tumor size and vascularity metrics to assess the effects of drug and gene treatments on vessel formation [Morikawa et al., 2002; Baluk et al., 2003; Ocak et al., 2007; Hashizume et al., 2010]. However, the 3-dimensional nature of most tumors presents a challenge for high-resolution imaging of tumor vessels.

\section{Quantification Methods in Mammalian Systems}

Selecting the appropriate metrics for a given model or analysis is essential to determine which aspects of sprouting are perturbed by a particular experimental manipulation. Rigorous quantification can help distinguish natural heterogeneity in morphology and behavior from differences that result from a specific genetic or pharmacological intervention. Assessment of vessel and sprout morphology often involves both manual and automated approaches as image quality can hamper complete automation of most measurements; however, image analysis tools such as Metamorph, ImageJ, and VESGEN 2D provide resources for incorporating automated strategies [Vickerman et al., 2009]. In the following section, we discuss several quantification methods that have been applied to mammalian models of blood vessel sprouting.

The vessels that develop in the in vitro bead assays rarely interconnect unless two beads are in close proximity, and thus a highly branched plexus does not often form. Instead, endothelial cells primarily sprout from the beads and from initial primitive vessels extending from the beads. The frequency of sprouting in these contexts can be measured to assess how experimental manipulations affect sprout initiation. Sprout thickness/diameter and sprout length quantification can provide further insight into how cells are allocated for vessel growth - i.e. for sprouting, vessel elongation, or radial expansion. Lumen frequency and size can also be quantified. Similar parameters can be applied to vessel sprouting from embryoid bodies imbedded in collagen as secondary sprouts also emerge from primary vessel extensions in this model [Chappell et al., 2009; Jakobsson et al., 2010]. Both models can be assessed for the spatial orientation of secondary sprouts relative to the primary vessel (e.g. sprout angle) and to other sprouts (e.g. distance between sprouts) to determine if vessel-intrinsic mechanisms are affected [Chappell et al., 2009].

The mechanisms underlying sprout initiation and sprout guidance share common features, but they also have distinct requirements such as the absolute versus relative VEGF-A levels [Gerhardt et al., 2003] and the proper spatial distribution of certain molecules such as Flt-1 [Chappell et al., 2009]. Overall vessel branching morphology results from the proper regulation of many cellular behaviors. Thus, quantifying vessel branching may reveal if one or more of these behaviors of vessel sprouting is defective and suggest additional measurements to complement initial observations.

The branching density of vessels derived from ES cells can be determined by measuring vessel branch points normalized to vessel length. The spacing between sprouts/ branches, the sprout angle relative to the parent vessel, and the number and angle of filopodia relative to the sprout axis are quantified to assess the degree to which a sprout is guided by local cues and is able to extend efficiently away from the parent vessel [Chappell et al., 2009]. 
Several in vitro and in situ sprouting assays are observable via live imaging. Therefore, the element of time can be included in the overall assessment of vessel sprouting. The rate and frequency of sprout formation, the speed of sprout migration, or changes in sprout directionality over time are measurable, and these measurements can contribute to an enhanced description of how sprouting is affected by experimental perturbations [Roberts et al., 2004; Chappell et al., 2009; Jakobsson et al., 2010].

In the developing retinal vasculature, assessing vessel density via branch point quantification is essential for determining differences between experimental groups as there is heterogeneity in vessel density even within one retina [Pitulescu et al., 2010]. Other metrics that quantify vessel perturbations include enumeration of tip cells extending from the vascular front, and filopodia number per tip cell and per vessel length [Hellstrom et al., 2007]. The angle and length of filopodia relative to the tip cell/ sprout and distance between sprouts can be measured to indicate changes in the spatial information guiding tip cell migration [Suchting et al., 2007; Chappell et al., 2009].

\section{Mechanisms of Blood Vessel Sprouting}

Blood vessels sprout in response to exogenous factors secreted by tissues requiring an increased vascular supply. The heterogeneous response of endothelial cells to these stimuli results in the organization and specialization of cells for particular functions. An endothelial 'tip' cell, for example, is selected to sprout outward from the parent vessel and lead the extending sprout to a target vessel or sprout for fusion and subsequent lumen formation. The following sections describe processes involved in blood vessel sprouting and their contribution to the expansion and patterning of the blood vasculature.

\section{Sprout Initiation}

Tip cell specification is important in the expansion of various tubular networks (fig. 1, stage I). Although the initial specification of an endothelial tip cell from a group of 'naïve' cells in a vessel is poorly understood, it may occur via competition. During Drosophila trachea formation, epithelial cells compete for the lead position of extending tracheal branches [Ghabrial and Krasnow, 2006]. A tip cell becomes specialized to lead the nascent branch by increased fibroblast growth factor (FGF) receptor (Breathless) activation and by lateral inhibition of trailing cells through Notch signaling. The tracheal tip cell uses numerous filopodia to sense environmental cues such as FGF (Branchless) and direct sprout extension [Ribeiro et al., 2002]. The growth cones of axons also interpret environmental spatial cues using filopodia [Kater and Rehder, 1995].

Once a vessel sprout forms, endothelial cells appear to compete similarly to take the lead position based on responsiveness to VEGF-A, a potent regulator of angiogenic sprouting [Jakobsson et al., 2010]. The VEGF tyrosine kinase receptor Flk-1 (VEGFR2) positively regulates endothelial migration, while the VEGF receptor Flt-1 (VEGFR1) acts primarily as a ligand sink [Kendall and Thomas, 1993]. Thus cells with high Flk-1 or low Flt-1 levels assume the tip cell position more frequently [Jakobsson et al., 2010], and the levels of these receptors are also regulated in part by Notch signaling (fig. 3) [Henderson et al., 2001; Holderfield et al., 2006; Suchting et al., 2007; Harrington et al., 2008; Phng et al., 2009; Funahashi et al., 2010; Jakobsson et al., 2010].

In addition to regulating VEGF receptor levels, the Notch pathway also modulates tip/stalk cell dynamics through lateral inhibition. The Notch signaling pathway involves 4 Notch receptors, Notch1-4, and the 5 ligands: Delta-like 1 (Dll1), Dll3, Dll4, and Jagged-1 (Jag-1) and Jag-2. Because these receptors and ligands are transmembrane proteins, signaling requires cells to be in close proximity. The Notch intracellular domain (NICD) is released from the cell membrane through proteolytic cleavage following the binding of a Notch receptor by a ligand on an adjacent cell. Downstream transcription targets are activated after this NICD translocates into the nucleus and forms an activating complex. When an endothelial cell expresses higher levels of Notch ligands than neighboring cells, adjacent endothelial cells experience increased Notch signaling which increases Flt-1 expression and prevents adoption of the tip cell phenotype.

Recent observations suggest that lateral inhibition facilitates tip cell specification at the outset of sprouting angiogenesis because VEGF-A induces Dll4 expression in endothelial cells that will adopt a tip cell phenotype (fig. 3) [Liu et al., 2003; Lobov et al., 2007; Suchting et al., 2007]. Additionally, endothelial cells deficient in Notch1 activity preferentially assume the tip cell position in mice [Hellstrom et al., 2007], while zebrafish endothelial cells overexpressing the NICD rarely have tip cell characteristics [Siekmann and Lawson, 2007]. Inhibiting Notch signaling by blocking the cleavage of NICD (i.e. via treatment with $\gamma$-secretase inhibitors such as DAPT) induces excessive tip cell specification in zebrafish and in mice 
[Hellstrom et al., 2007; Leslie et al., 2007]. Genetic disruptions of Dll4 in zebrafish and mice phenocopy defects seen in developing blood vessels treated with $\gamma$-secretase inhibitors. Morpholinos against the Notch pathway components Dll4 [Siekmann and Lawson, 2007], notch 1 b [Leslie et al., 2007], and recombining binding protein suppressor of hairless (Rbpja) [Siekmann and Lawson, 2007] cause hyperbranching in zebrafish. Interestingly, genetic manipulation of endothelial Notch 1 expression in mice does not always yield a sprouting phenotype [Limbourg et al., 2005; Krebs et al., 2010], suggesting that Notch regulation of sprouting is context dependent. Nevertheless, recent data supports a role for Notch signaling in regulating vessel sprouting by inhibiting tip cell specification.

Several angiogenic factors are also transcriptionally regulated by the Notch pathway [Siekmann et al., 2008], which likely contributes to tip cell specification or maintenance (fig. 3). For instance, Notch negatively regulates expression of the VEGF-A coreceptor Neuropilin-1 (Nrp-1) [Williams et al., 2006]. Tip cells also express high levels of Flt-4 (VEGFR3), and Notch inhibition upregulates Flt-4 expression and tip cell formation, which can be partially rescued with Flt- 4 neutralizing antibodies [Siekmann and Lawson, 2007; Tammela et al., 2008]. Interestingly, increased Notch signaling via introduction of constitutively active constructs also upregulates Flt- 4 expression and perturbs vessel formation [Shawber et al., 2007]. These apparent discrepancies may depend on tissue-specific requirements for the VEGF and Notch pathways. As stated briefly above, Flk-1 is negatively regulated by Notch signaling [Henderson et al., 2001; Holderfield et al., 2006], while Flt-1 is positively regulated (fig. 3) [Harrington et al., 2008; Funahashi et al., 2010]. Since Flt-1 modulates Flk-1 activation by VEGF [Roberts et al., 2004; Kappas et al., 2008], increased expression of Flt-1 by stalk cells dampens VEGF responsiveness and limits their capacity to sprout [Chappell et al., 2009; Jakobsson et al., 2010]. Thus, tip cell selection appears to be modulated through Notch regulation of multiple angiogenic factors.

Live imaging of angiogenic sprouts suggests that Notchmediated lateral inhibition and in turn the occupancy of the lead position are highly dynamic [Jakobsson et al., 2010]. This can hamper clear identification of tip cells, and expression of relevant markers shows small differences relative to neighboring cells in fixed images. Some markers expressed by tip cells include apelin, CXCR4, Dll4, Flk1, Flt-4, platelet-derived growth factor (PDGF)-b, and UNC5b [Gerhardt et al., 2003; Claxton and Fruttiger,

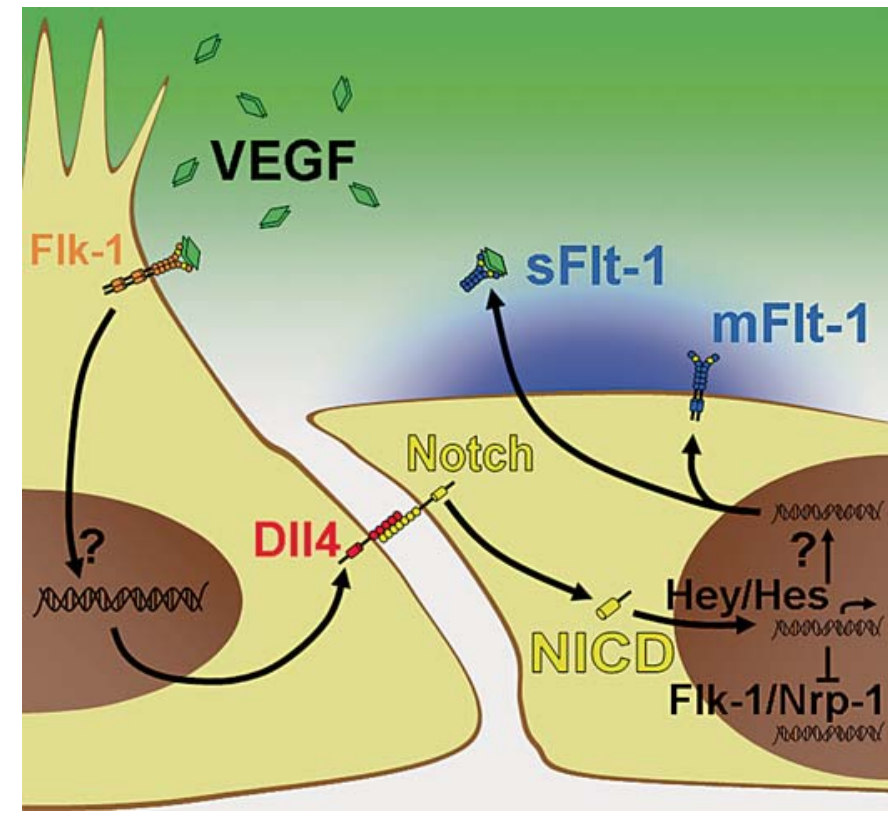

Fig. 3. Molecular regulation of blood vessel sprouting. The VEGFA ligand (green diamonds) binds the Flk-1 receptor (orange Y) on the tip cell, increasing Dll4 expression. The Dll4 ligand engages the Notch receptor on the neighboring lateral base cells and promotes cleavage of the NICD. Translocation of the NICD into the nucleus increases expression of downstream genes including Hey and Hes family genes, which may then decrease Flk-1 and Nrp-1 expression and increase expression of Flt-1 (blue Ys).

2004; Lu et al., 2004; Hellstrom et al., 2007; Siekmann and Lawson, 2007; del Toro et al., 2010; Strasser et al., 2010]. Thus, both expression patterns and morphological features such as lack of a lumen and extension of numerous long filopodia are used to distinguish tip cells in fixed images. Overall, tip cell specification is essential for sprout initiation and vascular branch formation.

\section{Sprout Guidance}

The role for VEGF-A as a guidance cue for endothelial sprouts has been well established [Gerhardt, 2008]. The three predominant VEGF-A isoforms, generated via alternative splicing, vary in their binding affinities for the ECM due to the presence or absence of heparin-binding domains [Tischer et al., 1991]. Proper spatial distribution of VEGF-A depends on variable ECM affinity, and genetic perturbation of VEGF-A isoforms disrupts vessel patterning [Ruhrberg et al., 2002; Stalmans et al., 2002]. We recently identified a mechanism by which soluble Flt1 (sFlt1) expressed by endothelial cells adjacent to an emerging sprout provide additional refinement of near- 
field VEGF-A gradients (fig. 3) [Chappell et al., 2009]. In this way, a more directed VEGF-A gradient is created to guide outward sprouting (fig. 1, stage II), and this guidance is compromised when these lateral base cells do not express sFlt-1. Additional reinforcement of local VEGF-A gradients may occur through the release of VEGF-A directly from endothelial cells [Lee et al., 2007; da Silva et al., 2010] or from proteolytic cleavage of the ECM [Helm et al., 2005; Vempati et al., 2010]. Alternatively, ECM retention of VEGF-A likely guides sprouting and promotes branch formation [Lee et al., 2005; Chen et al., 2010]. Thus, endothelial sprout guidance depends on various mechanisms that regulate spatial VEGF-A presentation.

Tip cell filopodia contain Flk-1 for sensing the VEGFA gradients described above (fig. 1, stage III) [Gerhardt et al., 2003]. In addition, integrins on these filopodia bind ECM components, facilitating migration along the matrix [Hynes, 2002; Anderson et al., 2004]. In certain contexts, vessel sprouts also interact with other cell types in the vicinity of sprouting, such as zebrafish intersegmental vessels and adjacent somites [Lawson and Weinstein, 2002; Isogai et al., 2003] and mouse retinal endothelium and underlying astrocytes [Dorrell et al., 2002; Gerhardt et al., 2003]. Sprout guidance from these cell-cell interactions often includes attractive-repulsive cues that have been adapted from the axonal guidance system [Carmeliet and Tessier-Lavigne, 2005; Adams and Eichmann, 2010] such as UNC5b interactions with netrin [Lu et al., 2004] and robo4 [Koch et al., 2011], or Nrp-1 with VEGFA [Gerhardt et al., 2004; Jones et al., 2008]. A nascent spout must therefore integrate guidance information from soluble cues, ECM elements, and other cells for proper outward migration.

\section{Sprout Maturation}

A sprouting vessel transitions into a functional vascular branch by fusing with a target sprout/vessel, developing a lumen, and becoming stable and quiescent (fig. 1, stages IV and V). Recent in vivo and computational evidence suggests that tip cell filopodia from approaching sprouts interact to initiate junction formation [Bentley et al., 2009]. These cells likely increase cell-cell junctions to maintain and reinforce their initial connection [Dorrell et al., 2002; Almagro et al., 2010]. Without junction reinforcement, cells may continue seeking another target, or they may ultimately retract. Embryonic macrophages may also facilitate sprout fusion in some contexts by bridging sprouts to their potential target [Fantin et al., 2010]. Thus, tip cell filopodia interactions initiate and reinforce of cell-cell contacts and sprout fusion. It remains unknown, however, exactly how a vessel sprout determines its target for fusion.

For blood to begin flowing through a new vessel branch, a connected sprout must ultimately acquire a functional lumen (fig. 1, stage IV) [Iruela-Arispe and Davis, 2009]. Recent studies indicate that the mechanisms involved in lumenization are context dependent. Tip cells in mouse retinal vessels do not have lumens in general, but the cell immediately behind the tip cell usually contains a patent lumen [Gerhardt et al., 2003]. In the developing mouse aorta, the lumen expands through orchestrated endothelial cell shape changes following changes in their polarity [Strilic et al., 2009]. Furthermore, the negative charge on apical surface glycoproteins generates electrostatic repulsion that helps force apart adjacent endothelial cells, and luminal expansion is disrupted by loss of this negative charge [Strilic et al., 2010]. In contrast, fusion of intracellular and intercellular vacuoles between and perhaps within endothelial cells is thought to result in lumen formation in vessels formed in the zebrafish trunk and in vitro 3 -dimensional collagen gels [Kamei et al., 2006; Blum et al., 2008]. These studies provide insight into the possible mechanisms governing lumen formation, yet our understanding of these processes is incomplete, particularly with respect to polarity cues in the endothelium and their role in lumen formation.

\section{Conclusions and Perspectives}

The last 5-10 years have refined our understanding of how blood vessels regulate sprouting and sprout fusion to form new networks. Numerous in vitro, in situ, and in vivo models that are genetically tractable allow for precise determination of mechanisms and pathways involved in sprout regulation. Since there are strong spatial and temporal components to the regulation of sprouting angiogenesis, the advent of models that allow for high-resolution confocal image analysis and live imaging have been critical to advancing our knowledge. Finally, our ability to rigorously measure and quantify aspects of vessel sprouting allows for more precise determination of subtle but real effects from normal heterogeneity in these processes. The advent of quantitative measures also permits better integration of experimental and computational models that are contributing to our knowledge of how angiogenesis is regulated [Bentley et al., 2008; Mac Gabhann and Popel, 2008; Merks et al., 2008; Peirce, 2008]. The concept that different stages of sprouting exist and may utilize different regulatory mechanisms should help 
refine even further the important unresolved issues in sprouting angiogenesis. Expanded insight into vessel sprouting will in turn guide treatment of pathological blood vessel formation by suggesting signaling pathways to target for limiting vessel growth [You et al., 2011], and it will contribute to the optimization of bioengineering strategies for tissue revascularization [Leslie-Barbick et al., 2011].

\section{Acknowledgements}

We thank members of the Bautch and Jin labs for stimulating discussions. This work was funded by NIH grants (HL43174 and HL86465 to V.L.B.), NIH NRSA Postdoctoral Fellowship F32 HL95359 (J.C.C.), and AHA Predoctoral Fellowship 10PRE3290010 (D.M.W.).

\section{References}

Adams, R.H., A. Eichmann (2010) Axon guid- Bentley, K., H. Gerhardt, P.A. Bates (2008) ance molecules in vascular patterning. Cold Spring Harb Perspect Biol 2: a001875.

Aiello, L.P. (2008) Targeting intraocular neovascularization and edema - one drop at a time. N Engl J Med 359: 967-969.

Almagro, S., C. Durmort, A. Chervin-Petinot, S. Heyraud, M. Dubois, O. Lambert, C. Maillefaud, E. Hewat, J.P. Schaal, P. Huber, D. Gulino-Debrac (2010) The motor protein myosin-X transports VE-cadherin along filopodia to allow the formation of early endothelial cell-cell contacts. Mol Cell Biol 30: 1703-1717.

Anderson, C.R., A.M. Ponce, R.J. Price (2004) Immunohistochemical identification of an extracellular matrix scaffold that microguides capillary sprouting in vivo. J Histochem Cytochem 52: 1063-1072.

Argraves, W.S., A.C. Larue, P.A. Fleming, C.J. Drake (2002) VEGF signaling is required for the assembly but not the maintenance of embryonic blood vessels. Dev Dyn 225: 298 304.

Baluk, P., S. Morikawa, A. Haskell, M. Mancuso, D.M. McDonald (2003) Abnormalities of basement membrane on blood vessels and endothelial sprouts in tumors. Am J Pathol 163: 1801-1815.

Bayless, K.J., G.E. Davis (2003) Sphingosine-1phosphate markedly induces matrix metalloproteinase and integrin-dependent human endothelial cell invasion and lumen formation in three-dimensional collagen and fibrin matrices. Biochem Biophys Res Commun 312: 903-913.

Bayless, K.J., H.I. Kwak, S.C. Su (2009) Investigating endothelial invasion and sprouting behavior in three-dimensional collagen matrices. Nat Protoc 4: 1888-1898.

Benedito, R., C. Roca, I. Sorensen, S. Adams, A. Gossler, M. Fruttiger, R.H. Adams (2009) The notch ligands Dll4 and Jagged1 have opposing effects on angiogenesis. Cell 137: 1124-1135.

Benest, A.V., S.J. Harper, S.Y. Herttuala, K. Alitalo, D.O. Bates (2008) VEGF-C induced angiogenesis preferentially occurs at a distance from lymphangiogenesis. Cardiovasc Res 78: 315-323. Agent-based simulation of notch-mediated tip cell selection in angiogenic sprout initialisation. J Theor Biol 250: 25-36.

Bentley, K., G. Mariggi, H. Gerhardt, P.A. Bates (2009) Tipping the balance: robustness of tip cell selection, migration and fusion in angiogenesis. PLoS Comput Biol 5: e1000549.

Blum, Y., H.G. Belting, E. Ellertsdottir, L. Herwig, F. Luders, M. Affolter (2008) Complex cell rearrangements during intersegmental vessel sprouting and vessel fusion in the zebrafish embryo. Dev Biol 316(2): 312-322.

-Carmeliet, P., M. Tessier-Lavigne (2005) Common mechanisms of nerve and blood vessel wiring. Nature 436: 193-200.

Cha, Y.R., B.M. Weinstein (2007) Visualization and experimental analysis of blood vessel formation using transgenic zebrafish. Birth Defects Res C Embryo Today 81: 286-296.

Chappell, J.C., S.M. Taylor, N. Ferrara, V.L. Bautch (2009) Local guidance of emerging vessel sprouts requires soluble Flt-1. Dev Cell 17: 377-386.

Chappell, J.C., D.M. Wiley, V.L. Bautch (2011) Regulation of blood vessel sprouting. Semin Cell Dev Biol, in press.

Chen, T.T., A. Luque, S. Lee, S.M. Anderson, T. Segura, M.L. Iruela-Arispe (2010) Anchorage of VEGF to the extracellular matrix conveys differential signaling responses to endothelial cells. J Cell Biol 188: 595-609.

Childs, S., J.N. Chen, D.M. Garrity, M.C. Fishman (2002) Patterning of angiogenesis in the zebrafish embryo. Development 129: $973-$ 982.

Claxton, S., M. Fruttiger (2004) Periodic Deltalike 4 expression in developing retinal arteries. Gene Expr Patterns 5: 123-127.

Crosby, C.V., P.A. Fleming, W.S. Argraves, M. Corada, L. Zanetta, E. Dejana, C.J. Drake (2005) VE-cadherin is not required for the formation of nascent blood vessels but acts to prevent their disassembly. Blood 105: 27712776.

da Silva, R.G., B. Tavora, S.D. Robinson, L.E. Reynolds, C. Szekeres, J. Lamar, S. Batista, V. Kostourou, M.A. Germain, A.R. Reynolds, D.T. Jones, A.R. Watson, J.L. Jones, A. Harris, I.R. Hart, M.L. Iruela-Arispe, C.M. Di- persio, J.A. Kreidberg, K.M. Hodivala-Dilke (2010) Endothelial alpha3beta1-integrin represses pathological angiogenesis and sustains endothelial-VEGF. Am J Pathol 177: 1534-1548.

del Toro, R., C. Prahst, T. Mathivet, G. Siegfried, J.S. Kaminker, B. Larrivee, C. Breant, Duarte, N. Takakura, A. Fukamizu, J. Penninger, A. Eichmann (2010) Identification and functional analysis of endothelial tip cell-enriched genes. Blood 116: 4025-4033.

Dietrich, F., P.I. Lelkes (2006) Fine-tuning of a three-dimensional microcarrier-based angiogenesis assay for the analysis of endothelial-mesenchymal cell co-cultures in fibrin and collagen gels. Angiogenesis 9: 111-125.

Doetschman, T.C., H. Eistetter, M. Katz, W Schmidt, R. Kemler (1985) The in vitro development of blastocyst-derived embryonic stem cell lines: formation of visceral yolk sac, blood islands and myocardium. J Embryol Exp Morphol 87: 27-45.

Dorrell, M.I., E. Aguilar, M. Friedlander (2002) Retinal vascular development is mediated by endothelial filopodia, a preexisting astrocytic template and specific R-cadherin adhesion. Invest Ophthalmol Vis Sci 43: 35003510.

Downs, K.M., R. Temkin, S. Gifford, J. McHugh (2001) Study of the murine allantois by allantoic explants. Dev Biol 233: 347-364.

Drake, C.J., P.A. Fleming (2000) Vasculogenesis in the day 6.5 to 9.5 mouse embryo. Blood 95: 1671-1679.

Eisen, J.S., J.C. Smith (2008) Controlling morpholino experiments: don't stop making antisense. Development 135: 1735-1743.

Fantin, A., J.M. Vieira, G. Gestri, L. Denti, Q. Schwarz, S. Prykhozhij, F. Peri, S.W. Wilson, C. Ruhrberg (2010) Tissue macrophages act as cellular chaperones for vascular anastomosis downstream of VEGF-mediated endothelial tip cell induction. Blood 116: 829840.

Fioretto, P., P.M. Dodson, D. Ziegler, R.S. Rosenson (2010) Residual microvascular risk in diabetes: unmet needs and future directions. Nat Rev Endocrinol 6: 19-25.

Fruttiger, M. (2007) Development of the retinal vasculature. Angiogenesis 10: 77-88. 
-Funahashi, Y., C.J. Shawber, M. Vorontchikhina, A. Sharma, H.H. Outtz, J. Kitajewski (2010) Notch regulates the angiogenic response via induction of VEGFR-1. J Angiogenes Res 2: 3.

Garcia, M.D., R.S. Udan, A.K. Hadjantonakis, M.E. Dickinson (2011) Live imaging of mouse embryos. Cold Spring Harb Protoc 2011: pdb.top104.

- Gerhardt, H. (2008) VEGF and endothelial guidance in angiogenic sprouting. Organogenesis 4: 241-246.

Gerhardt, H., M. Golding, M. Fruttiger, C. Ruhrberg, A. Lundkvist, A. Abramsson, M. Jeltsch, C. Mitchell, K. Alitalo, D. Shima, C. Betsholtz (2003) VEGF guides angiogenic sprouting utilizing endothelial tip cell filopodia. J Cell Biol 161: 1163-1177.

-Gerhardt, H., C. Ruhrberg, A. Abramsson, H. Fujisawa, D. Shima, C. Betsholtz (2004) Neuropilin-1 is required for endothelial tip cell guidance in the developing central nervous system. Dev Dyn 231: 503-509.

Ghabrial, A.S., M.A. Krasnow (2006) Social interactions among epithelial cells during tracheal branching morphogenesis. Nature 441 : 746-749.

Goto, F., K. Goto, K. Weindel, J. Folkman (1993) Synergistic effects of vascular endothelial growth factor and basic fibroblast growth factor on the proliferation and cord formation of bovine capillary endothelial cells within collagen gels. Lab Invest 69: 508-517.

-Harrington, L.S., R.C. Sainson, C.K. Williams, J.M. Taylor, W. Shi, J.L. Li, A.L. Harris (2008) Regulation of multiple angiogenic pathways by Dll4 and Notch in human umbilical vein endothelial cells. Microvasc Res 75: 144-154.

Hashizume, H., B.L. Falcon, T. Kuroda, P. Baluk, A. Coxon, D. Yu, J.V. Bready, J.D. Oliner, D.M. McDonald (2010) Complementary actions of inhibitors of angiopoietin-2 and VEGF on tumor angiogenesis and growth. Cancer Res 70: 2213-2223.

Heath, V.L., R. Bicknell (2009) Anticancer strategies involving the vasculature. Nat Rev Clin Oncol 6: 395-404.

Hellstrom, M., L.K. Phng, J.J. Hofmann, E. Wallgard, L. Coultas, P. Lindblom, J. Alva, A.K. Nilsson, L. Karlsson, N. Gaiano, K. Yoon, J. Rossant, M.L. Iruela-Arispe, M. Kalen, H. Gerhardt, C. Betsholtz (2007) Dll4 signalling through Notch1 regulates formation of tip cells during angiogenesis. Nature 445: $776-$ 780 .

Helm, C.L., M.E. Fleury, A.H. Zisch, F. Boschetti, M.A. Swartz (2005) Synergy between interstitial flow and VEGF directs capillary morphogenesis in vitro through a gradient amplification mechanism. Proc Natl Acad Sci USA 102: 15779-15784.

Henderson, A.M., S.J. Wang, A.C. Taylor, M. Aitkenhead, C.C. Hughes (2001) The basic helix-loop-helix transcription factor HESR1 regulates endothelial cell tube formation. J Biol Chem 276: 6169-6176.
Hermans, K., F. Claes, W. Vandevelde, W. Zheng, I. Geudens, F. Orsenigo, F. De Smet, E. Gjini, K. Anthonis, B. Ren, D. Kerjaschki, M. Autiero, A. Ny, M. Simons, M. Dewerchin, S. Schulte-Merker, E. Dejana, K. Alitalo, P. Carmeliet (2010) Role of synectin in lymphatic development in zebrafish and frogs. Blood 116: 3356-3366.

-Hernandez Vera, R., E. Genove, L. Alvarez, S. Borros, R. Kamm, D. Lauffenburger, C.E. Semino (2009) Interstitial fluid flow intensity modulates endothelial sprouting in restricted Src-activated cell clusters during capillary morphogenesis. Tissue Eng Part A 15: 175-185.

Holderfield, M.T., A.M. Henderson Anderson, H. Kokubo, M.T. Chin, R.L. Johnson, C.C. Hughes (2006) HESR1/CHF2 suppresses VEGFR2 transcription independent of binding to E-boxes. Biochem Biophys Res Commun 346: 637-648.

Hu, G., J. Tang, B. Zhang, Y. Lin, J. Hanai, J. Galloway, V. Bedell, N. Bahary, Z. Han, R. Ramchandran, B. Thisse, C. Thisse, L.I. Zon, V.P. Sukhatme (2006) A novel endothelial-specific heat shock protein HspA12B is required in both zebrafish development and endothelial functions in vitro. J Cell Sci 119: 41174126.

Hynes, R.O. (2002) A reevaluation of integrins as regulators of angiogenesis. Nat Med 8: 918 921.

Iruela-Arispe, M.L., G.E. Davis (2009) Cellular and molecular mechanisms of vascular lumen formation. Dev Cell 16: 222-231.

Isogai, S., N.D. Lawson, S. Torrealday, M. Horiguchi, B.M. Weinstein (2003) Angiogenic network formation in the developing vertebrate trunk. Development 130: 5281-5290.

Jakobsson, L., A. Domogatskaya, K. Tryggvason, D. Edgar, L. Claesson-Welsh (2007a) Laminin deposition is dispensable for vasculogenesis but regulates blood vessel diameter independent of flow. FASEB J 22: 1530-1539.

Jakobsson, L., C.A. Franco, K. Bentley, R.T. Collins, B. Ponsioen, I.M. Aspalter, I. Rosewell, M. Busse, G. Thurston, A. Medvinsky, S. Schulte-Merker, H. Gerhardt (2010) Endothelial cells dynamically compete for the tip cell position during angiogenic sprouting. Nat Cell Biol 12: 943-953.

-Jakobsson, L., J. Kreuger, L. Claesson-Welsh (2007b) Building blood vessels - stem cell models in vascular biology. J Cell Biol 177: 751-755.

Jakobsson, L., J. Kreuger, K. Holmborn, L. Lundin, I. Eriksson, L. Kjellen, L. ClaessonWelsh (2006) Heparan sulfate in trans potentiates VEGFR-mediated angiogenesis. Dev Cell 10: 625-634.

Jones, E.A., L. Yuan, C. Breant, R.J. Watts, A. Eichmann (2008) Separating genetic and hemodynamic defects in neuropilin 1 knockout embryos. Development 135: 2479-2488.

Kamei, M., S. Isogai, W. Pan, B.M. Weinstein (2010) Imaging blood vessels in the zebrafish. Methods Cell Biol 100: 27-54.
Kamei, M., W.B. Saunders, K.J. Bayless, L. Dye, G.E. Davis, B.M. Weinstein (2006) Endothelial tubes assemble from intracellular vacuoles in vivo. Nature 442: 453-456.

Kang, H., K.J. Bayless, R. Kaunas (2008) Fluid shear stress modulates endothelial cell invasion into three-dimensional collagen matrices. Am J Physiol Heart Circ Physiol 295: H2087-H2097.

Kappas, N.C., G. Zeng, J.C. Chappell, J.B. Kearney, S. Hazarika, K.G. Kallianos, C. Patterson, B.H. Annex, V.L. Bautch (2008) The VEGF receptor Flt-1 spatially modulates Flk1 signaling and blood vessel branching. J Cell Biol 181: 847-858.

Kater, S.B., V. Rehder (1995) The sensory-motor role of growth cone filopodia. Curr Opin Neurobiol 5: 68-74.

Kearney, J.B., N.C. Kappas, C. Ellerstrom, F.W. DiPaola, V.L. Bautch (2004) The VEGF receptor flt-1 (VEGFR-1) is a positive modulator of vascular sprout formation and branching morphogenesis. Blood 103: 4527-4535.

Kendall, R.L., K.A. Thomas (1993) Inhibition of vascular endothelial cell growth factor activity by an endogenously encoded soluble receptor. Proc Natl Acad Sci USA 90: $10705-$ 10709.

Koch, A.W., T. Mathivet, B. Larrivee, R.K. Tong, J. Kowalski, L. Pibouin-Fragner, K. Bouvree, S. Stawicki, K. Nicholes, N. Rathore, S.J. Scales, E. Luis, R. del Toro, C. Freitas, C. Breant, A. Michaud, P. Corvol, J.L. Thomas, Y. Wu, F. Peale, R.J. Watts, M. Tessier-Lavigne, A. Bagri, A. Eichmann (2011) Robo4 maintains vessel integrity and inhibits angiogenesis by interacting with UNC5B. Dev Cell 20: 33-46.

Koh, W., A.N. Stratman, A. Sacharidou, G.E. Davis (2008) In vitro three dimensional collagen matrix models of endothelial lumen formation during vasculogenesis and angiogenesis. Methods Enzymol 443: 83-101.

Krebs, L.T., C. Starling, A.V. Chervonsky, T. Gridley (2010) Notch1 activation in mice causes arteriovenous malformations phenocopied by ephrinB2 and EphB4 mutants. Genesis 48: 146-150.

Larina, I.V., W. Shen, O.G. Kelly, A.K. Hadjantonakis, M.H. Baron, M.E. Dickinson (2009) A membrane associated mCherry fluorescent reporter line for studying vascular remodeling and cardiac function during murine embryonic development. Anat Rec (Hoboken) 292: 333-341.

Lawson, N.D., A.M. Vogel, B.M. Weinstein (2002) Sonic hedgehog and vascular endothelial growth factor act upstream of the Notch pathway during arterial endothelial differentiation. Dev Cell 3: 127-136.

Lawson, N.D., B.M. Weinstein (2002) In vivo imaging of embryonic vascular development using transgenic zebrafish. Dev Biol 248: 307-318. 
Lee, S., T.T. Chen, C.L. Barber, M.C. Jordan, J. Murdock, S. Desai, N. Ferrara, A. Nagy, K.P. Roos, M.L. Iruela-Arispe (2007) Autocrine VEGF signaling is required for vascular homeostasis. Cell 130: 691-703.

Lee, S., S.M. Jilani, G.V. Nikolova, D. Carpizo, M.L. Iruela-Arispe (2005) Processing of VEGF-A by matrix metalloproteinases regulates bioavailability and vascular patterning in tumors. J Cell Biol 169: 681-691.

Leslie, J.D., L. Ariza-McNaughton, A.L. Bermange, R. McAdow, S.L. Johnson, J. Lewis (2007) Endothelial signalling by the Notch ligand Delta-like 4 restricts angiogenesis. Development 134: 839-844.

Leslie-Barbick, J.E., J.E. Saik, D.J. Gould, M.E. Dickinson, J.L. West (2011) The promotion of microvasculature formation in poly(ethylene glycol) diacrylate hydrogels by an immobilized VEGF-mimetic peptide. Biomaterials 32: 5782-5789.

Li, X., L. Claesson-Welsh, M. Shibuya (2008) VEGF receptor signal transduction. Methods Enzymol 443: 261-284.

-Limbourg, F.P., K. Takeshita, F. Radtke, R.T. Bronson, M.T. Chin, J.K. Liao (2005) Essential role of endothelial Notch1 in angiogenesis. Circulation 111: 18261832.

Liu, H., B. Chen, B. Lilly (2008) Fibroblasts potentiate blood vessel formation partially through secreted factor TIMP-1. Angiogenesis 11: 223-234.

- Liu, Z.J., T. Shirakawa, Y. Li, A. Soma, M. Oka, G.P. Dotto, R.M. Fairman, O.C. Velazquez, M. Herlyn (2003) Regulation of Notch1 and Dll4 by vascular endothelial growth factor in arterial endothelial cells: implications for modulating arteriogenesis and angiogenesis. Mol Cell Biol 23: 14-25.

Lobov, I.B., R.A. Renard, N. Papadopoulos, N.W. Gale, G. Thurston, G.D. Yancopoulos, S.J. Wiegand (2007) Delta-like ligand 4 (Dll4) is induced by VEGF as a negative regulator of angiogenic sprouting. Proc Natl Acad Sci USA 104: 3219-3224.

Lu, X., F. Le Noble, L. Yuan, Q. Jiang, B. De Lafarge, D. Sugiyama, C. Breant, F. Claes, F. De Smet, J.L. Thomas, M. Autiero, P. Carmeliet, M. Tessier-Lavigne, A. Eichmann (2004) The netrin receptor UNC5B mediates guidance events controlling morphogenesis of the vascular system. Nature 432 179-186.

Ma, A., R. Lin, P.K. Chan, J.C. Leung, L.Y. Chan, A. Meng, C.M. Verfaillie, R. Liang, A.Y. Leung (2007) The role of survivin in angiogenesis during zebrafish embryonic development. BMC Dev Biol 7: 50.

Mac Gabhann, F., A.S. Popel (2008) Systems biology of vascular endothelial growth factors. Microcirculation 15: 715-738.

Megason, S.G., S.E. Fraser (2003) Digitizing life at the level of the cell: high-performance laser-scanning microscopy and image analysis for in toto imaging of development. Mech Dev 120: 1407-1420.
Merks, R.M., E.D. Perryn, A. Shirinifard, J.A. Glazier (2008) Contact-inhibited chemotaxis in de novo and sprouting blood-vessel growth. PLoS Comput Biol 4: e1000163.

Morikawa, S., P. Baluk, T. Kaidoh, A. Haskell, R.K. Jain, D.M. McDonald (2002) Abnormalities in pericytes on blood vessels and endothelial sprouts in tumors. Am J Pathol 160: 985-1000.

Nakatsu, M.N., C.C. Hughes (2008) An optimized three-dimensional in vitro model for the analysis of angiogenesis. Methods Enzymol 443: 65-82.

Nehls, V., D. Drenckhahn (1995) A novel, microcarrier-based in vitro assay for rapid and reliable quantification of three-dimensional cell migration and angiogenesis. Microvasc Res 50: 311-322.

-Nehls, V., E. Schuchardt, D. Drenckhahn (1994) The effect of fibroblasts, vascular smooth muscle cells, and pericytes on sprout formation of endothelial cells in a fibrin gel angiogenesis system. Microvasc Res 48: 349-363.

Ng, Y.S., M. Ramsauer, R.M. Loureiro, P.A. D'Amore (2004) Identification of genes involved in VEGF-mediated vascular morphogenesis using embryonic stem cell-derived cystic embryoid bodies. Lab Invest 84: 12091218.

Nicoli, S., C. Standley, P. Walker, A. Hurlstone, K.E. Fogarty, N.D. Lawson (2010) MicroRNA-mediated integration of haemodynamics and Vegf signalling during angiogenesis. Nature 464: 1196-1200.

Ocak, I., P. Baluk, T. Barrett, D.M. McDonald, P. Choyke (2007) The biologic basis of in vivo angiogenesis imaging. Front Biosci 12: 36013616.

Patel, N.S., J.L. Li, D. Generali, R. Poulsom, D.W. Cranston, A.L. Harris (2005) Upregulation of delta-like 4 ligand in human tumor vasculature and the role of basal expression in endothelial cell function. Cancer Res 65: 86908697.

Peirce, S.M. (2008) Computational and mathematical modeling of angiogenesis. Microcirculation 15: 739-751.

- Perryn, E.D., A. Czirok, C.D. Little (2008) Vascular sprout formation entails tissue deformations and VE-cadherin-dependent cellautonomous motility. Dev Biol 313: 545-555.

Phng, L.K., H. Gerhardt (2009) Angiogenesis: a team effort coordinated by notch. Dev Cell 16: 196-208.

Phng, L.K., M. Potente, J.D. Leslie, J. Babbage, D. Nyqvist, I. Lobov, J.K. Ondr, S. Rao, R.A. Lang, G. Thurston, H. Gerhardt (2009) Nrarp coordinates endothelial Notch and Wnt signaling to control vessel density in angiogenesis. Dev Cell 16: 70-82.

Pitulescu, M.E., I. Schmidt, R. Benedito, R.H. Adams (2010) Inducible gene targeting in the neonatal vasculature and analysis of retinal angiogenesis in mice. Nat Protoc 5: 15181534 .
Ribeiro, C., A. Ebner, M. Affolter (2002) In vivo imaging reveals different cellular functions for FGF and Dpp signaling in tracheal branching morphogenesis. Dev Cell 2: 677683.

Ridgway, J., G. Zhang, Y. Wu, S. Stawicki, W.C. Liang, Y. Chanthery, J. Kowalski, R.J. Watts, C. Callahan, I. Kasman, M. Singh, M. Chien, C. Tan, J.A. Hongo, F. de Sauvage, G. Plowman, M. Yan (2006) Inhibition of Dll4 signalling inhibits tumour growth by deregulating angiogenesis. Nature 444: 1083-1087.

Risau, W. (1997) Mechanisms of angiogenesis. Nature 386: 671-674.

Risau, W., H. Sariola, H.G. Zerwes, J. Sasse, P. Ekblom, R. Kemler, T. Doetschman (1988) Vasculogenesis and angiogenesis in embryonic-stem-cell-derived embryoid bodies. Development 102: 471-478.

Roberts, D.M., J.B. Kearney, J.H. Johnson, M.P. Rosenberg, R. Kumar, V.L. Bautch (2004) The vascular endothelial growth factor (VEGF) receptor Flt-1 (VEGFR-1) modulates Flk-1 (VEGFR-2) signaling during blood vessel formation. Am J Pathol 164: 15311535

Roca, C., R.H. Adams (2007) Regulation of vascular morphogenesis by Notch signaling. Genes Dev 21: 2511-2524.

Ruhrberg, C., H. Gerhardt, M. Golding, R. Watson, S. Ioannidou, H. Fujisawa, C. Betsholtz, D.T. Shima (2002) Spatially restricted patterning cues provided by heparin-binding VEGF-A control blood vessel branching morphogenesis. Genes Dev 16: 2684-2698.

-Sainson, R.C., J. Aoto, M.N. Nakatsu, M. Holderfield, E. Conn, E. Koller, C.C. Hughes (2005) Cell-autonomous notch signaling regulates endothelial cell branching and proliferation during vascular tubulogenesis. FASEB J 19: 1027-1029.

-Sawamiphak, S., M. Ritter, A. Acker-Palmer (2010a) Preparation of retinal explant cultures to study ex vivo tip endothelial cell responses. Nat Protoc 5: 1659-1665.

- Sawamiphak, S., S. Seidel, C.L. Essmann, G.A. Wilkinson, M.E. Pitulescu, T. Acker, A. Acker-Palmer (2010b) Ephrin-B2 regulates VEGFR2 function in developmental and tumour angiogenesis. Nature 465: 487-491.

-Shawber, C.J., Y. Funahashi, E. Francisco, M. Vorontchikhina, Y. Kitamura, S.A. Stowell, V. Borisenko, N. Feirt, S. Podgrabinska, K. Shiraishi, K. Chawengsaksophak, J. Rossant, D. Accili, M. Skobe, J. Kitajewski (2007) Notch alters VEGF responsiveness in human and murine endothelial cells by direct regulation of VEGFR-3 expression. J Clin Invest 117: 3369-3382.

-Siekmann, A.F., L. Covassin, N.D. Lawson (2008) Modulation of VEGF signalling output by the Notch pathway. Bioessays 30:303313 .

Siekmann, A.F., N.D. Lawson (2007) Notch signalling limits angiogenic cell behaviour in developing zebrafish arteries. Nature 445: 781-784. 
-Stalmans, I., Y.S. Ng, R. Rohan, M. Fruttiger, A. Bouche, A. Yuce, H. Fujisawa, B. Hermans, M. Shani, S. Jansen, D. Hicklin, D.J. Anderson, T. Gardiner, H.P. Hammes, L. Moons, M. Dewerchin, D. Collen, P. Carmeliet, P.A. D'Amore (2002) Arteriolar and venular patterning in retinas of mice selectively expressing VEGF isoforms. J Clin Invest 109: $327-$ 336.

-Strasser, G.A., J.S. Kaminker, M. Tessier-Lavigne (2010) Microarray analysis of retinal endothelial tip cells identifies CXCR4 as a mediator of tip cell morphology and branching. Blood 115: 5102-5110.

-Stratman, A.N., K.M. Malotte, R.D. Mahan, M.J. Davis, G.E. Davis (2009) Pericyte recruitment during vasculogenic tube assembly stimulates endothelial basement membrane matrix formation. Blood 114: 5091-5101.

-Strilic, B., J. Eglinger, M. Krieg, M. Zeeb, J. Axnick, P. Babal, D.J. Muller, E. Lammert (2010) Electrostatic cell-surface repulsion initiates lumen formation in developing blood vessels. Curr Biol 20: 2003-2009.

-Strilic, B., T. Kucera, J. Eglinger, M.R. Hughes, K.M. McNagny, S. Tsukita, E. Dejana, N. Ferrara, E. Lammert (2009) The molecular basis of vascular lumen formation in the developing mouse aorta. Dev Cell 17: 505-515.

Suchting, S., C. Freitas, F. le Noble, R. Benedito, C. Breant, A. Duarte, A. Eichmann (2007) The Notch ligand Delta-like 4 negatively regulates endothelial tip cell formation and vessel branching. Proc Natl Acad Sci USA 104: 3225-3230.
Tammela, T., G. Zarkada, E. Wallgard, A. Murtomaki, S. Suchting, M. Wirzenius, M. Waltari, M. Hellstrom, T. Schomber, R. Peltonen, C. Freitas, A. Duarte, H. Isoniemi, P. Laakkonen, G. Christofori, S. Yla-Herttuala, M. Shibuya, B. Pytowski, A. Eichmann, C. Betsholtz, K. Alitalo (2008) Blocking VEGFR-3 suppresses angiogenic sprouting and vascular network formation. Nature 454: 656-660.

Tischer, E., R. Mitchell, T. Hartman, M. Silva, D. Gospodarowicz, J.C. Fiddes, J.A. Abraham (1991) The human gene for vascular endothelial growth factor: multiple protein forms are encoded through alternative exon splicing. J Biol Chem 266: 11947-11954.

Tran, T.C., B. Sneed, J. Haider, D. Blavo, A. White, T. Aiyejorun, T.C. Baranowski, A.L. Rubinstein, T.N. Doan, R. Dingledine, E.M. Sandberg (2007) Automated, quantitative screening assay for antiangiogenic compounds using transgenic zebrafish. Cancer Res 67: 11386-11392.

-Vempati, P., F. Mac Gabhann, A.S. Popel (2010) Quantifying the proteolytic release of extracellular matrix-sequestered VEGF with a computational model. PLoS One 5: e11860.

Vickerman, M.B., P.A. Keith, T.L. McKay, D.J. Gedeon, M. Watanabe, M. Montano, G. Karunamuni, P.K. Kaiser, J.E. Sears, Q. Ebrahem, D. Ribita, A.G. Hylton, P. ParsonsWingerter (2009) VESGEN 2D: automated, user-interactive software for quantification and mapping of angiogenic and lymphangiogenic trees and networks. Anat Rec (Hoboken) 292: 320-332.

-Vickerman, V., J. Blundo, S. Chung, R. Kamm (2008) Design, fabrication and implementation of a novel multi-parameter control microfluidic platform for three-dimensional cell culture and real-time imaging. Lab Chip 8: 1468-1477.
Wang, R., R. Clark, V.L. Bautch (1992) Embryonic stem cell-derived cystic embryoid bodies form vascular channels: an in vitro model of blood vessel development. Development 114: 303-316.

Wiley, D.M., J. Kim, J. Hao, C.C. Hong, V.L. Bautch, S.W. Jin (2011) Distinct signaling pathways regulate sprouting angiogenesis from the dorsal aorta and axial vein. Nat Cell Biol 13: 686-692.

Williams, C.K., J.L. Li, M. Murga, A.L. Harris, G. Tosato (2006) Up-regulation of the Notch ligand Delta-like 4 inhibits VEGF-induced endothelial cell function. Blood 107: 931939.

Winderlich, M., L. Keller, G. Cagna, A. Broermann, O. Kamenyeva, F. Kiefer, U. Deutsch, A.F. Nottebaum, D. Vestweber (2009) VE-PTP controls blood vessel development by balancing Tie-2 activity. J Cell Biol 185: 657-671.

You, W.K., B. Sennino, C.W. Williamson, B. Falcon, H. Hashizume, L.C. Yao, D.T. Aftab, D.M. McDonald (2011) VEGF and c-Met blockade amplify angiogenesis inhibition in pancreatic islet cancer. Cancer Res 71: 47584768.

Zeng, G., V.L. Bautch (2009) Differentiation and dynamic analysis of primitive vessels from embryonic stem cells. Methods Mol Biol 482: 333-344. 